\title{
THE CURRENT SITUATION OF FAMILY EDUCATION AND SCHOOL AND KINDERGARTEN ADMISSION OF MIGRANT CHILDREN IN ZHEJIANG PROVINCE, CHINA: A SURVEY OF HANGZHOU, NINGBO AND JIAXINGi
}

Weijia Gao,
Yingying Ge,
Yiting Feng,
Shuqin Jiang,
Man Wu,
Yang Fengii
Zhejiang International Studies University,
Zhejiang, China

\begin{abstract}
:
Based on a survey of 322 parents of migrant children aged 3 to 10 in Hangzhou, Ningbo and Jiaxing, Zhejiang Province, China, the study found that nearly $70 \%$ of parents have been working in Zhejiang for 5-10 years, and 28\% of them have worked for more than 10 years; $94 \%$ of them hold agricultural household registration and $6 \%$ of them hold nonagricultural household registration. Nearly $70 \%$ of these families have 2 to 3 children and $16 \%$ of them have 4 children. Those children who can get into the local public kindergartens and primary schools are all study in the local institutions and most schoolaged children and the majority of pre-school children who do not meet the admission requirements for local public kindergartens and primary schools return to their hometown due to the pressure of tuition fees. At the same time, family education is not efficient, more than half of the children's spare time is occupied by television and video games, the proportion of reading and sports activities is only a little more than $10 \%$. Most parents have little time to read, do homework and physical exercise with their children, because of their heavy work or low level of education. This paper puts forward some relevant countermeasures and suggestions, hoping to change this situation.
\end{abstract}

\footnotetext{
${ }^{\text {i }}$ Funded Project: This paper is the result of "Investigation and Countermeasure Research on the Current Situation of School Entrance and Family Education of Migrant Children in Zhejiang Province", which is supported by the Training Project of Innovation and Entrepreneurship Plan for College Students of Zhejiang International Studies University in 2019 (Project No.: 080700192019).

ii Correspondence: email yang.feng@zisu.edu.cn
} 
Keywords: Zhejiang, China; migrant children; admission to school; family education; investigation and suggestion on the current situation

\section{Introduction}

With the continuous development of China's economy, the number of migrant workers in Zhejiang Province is rising. In Wenzhou City, Ningbo City and other places, the population of migrant workers has been close to the local population. Migrant population of Zhejiang reached more than 40 million in 2017, including more than 30 million migrant workers from other provinces (Zhou, 2019). These migrant workers have made great contributions to the industrial upgrading and economic development of the province. The children of some migrant workers followed them to Zhejiang to live and study, which is called migrant children in China (UNICEF, 2015).

Because most of the migrant workers are farmers in underdeveloped areas of China, their own limited education level, and the heavy load of blue-collar work, there is no time for them to accompany their children, thus the family education of the children is not ideal (Chen, 2019). At the same time, due to the shortage of household registration and educational resources, compared with the local children, these migrant children are subject to a lot of restrictions (Liu \& Li, 2019). The education of children seriously affects these parents' work mentality and stability of work. It also directly affects the economic development, social stability and the realization of Chinese Dream in the province (Wang, 2020).

Kindergartens and primary schools are the key periods for children's intellectual development and behavior habits. Can children's multiple intelligence be effectively developed, and their various good behavior habits be developed in this period is of great significance to their future academic and professional development (Zhang Sheng et al., 2017).

There is no relevant research on this issue in Zhejiang Province of China through literature search in China and abroad. Therefore, the research group hopes to fill this gap through this survey, deeply understand the family education and enrollment of migrant children in Zhejiang Province, analyze the existing problems and difficulties, propose corresponding solutions, provide some effective family education strategies for the parents of migrant children, and provide some solutions for the local education authorities to solve the problem of migrant children's enrollment. It is of great significance to solve the worries of migrant families and promote the harmonious development of society. 


\section{Investigation design}

\subsection{Respondents}

Three hundred parents and their 3-10 years old children who come to Zhejiang for work were randomly selected for subjects.

\subsection{Place of investigation}

One to two primary schools and kindergartens and one to two residential districts, and the parents and children of 50 to 60 families in each city of Hangzhou, Ningbo and Jiaxing were randomly selected.

\subsection{Time of investigation}

June-October in 2019.

\subsection{Mode of sampling}

The sampling plan of this investigation is to random sampling at class in the primary schools and the kindergartens. The reason to choose Hangzhou, Ningbo and Jiaxing is these three cities are the big and medium-sized cities with relatively rapid economic development in Zhejiang Province, and there are a large number of migrant children in Zhejiang, and the results of the investigation can be a good representative of Zhejiang Province.

\subsection{Investigation tools and investigation contents}

According to the questionnaire on family education and entrance examination of migrant children in Zhejiang, the questionnaire is divided into 8 dimensions, and the main contents are as follows: the number of children in the family; who take care of the children daily, send the children to and from school, as well as homework tutoring; parent-child reading; tutorial classes and other family education; whether the children attend public or private kindergartens or primary schools; parents' tolerance to tuition fees; satisfaction with the quality of education; expectations for compulsory education, and so on.

\subsection{Method of data analysis}

According to the above survey indicators, the family education and the current situation of kindergarten and school admission in different cities were analyzed.

\section{Survey results and analysis}

This survey investigated the family, study and life situation of migrant children in Hangzhou, Jiaxing and Ningbo, and 356 questionnaires (including 174 in Hangzhou, 107 in Jiaxing and 75 in Ningbo) were distributed, and 351 copies were recovered (including 173 in Hangzhou, 106 in Jiaxing and 72 in Ningbo), 322 copies were valid (including 162 
Weijia Gao, Yingying Ge, Yiting Feng, Shuqin Jiang, Man Wu, Yang Feng

THE CURRENT SITUATION OF FAMILY EDUCATION AND SCHOOL AND KINDERGARTEN

ADMISSION OF MIGRANT CHILDREN IN ZHEJIANG PROVINCE, CHINA:

A SURVEY OF HANGZHOU, NINGBO AND JIAXING

in Hangzhou, 98 in Jiaxing and 62 in Ningbo), with a 90.1\% effective questionnaire recovery rate.

The summary of the survey data of the three places is as follows:

Table 1: Summary of Family Education and Kindergarten /

Primary School Enrollment of Migrant Children in Zhejiang

\begin{tabular}{|c|c|c|c|c|}
\hline $\begin{array}{ll}\text { Survey Items } & \text { Survey Places } \\
\end{array}$ & Hangzhou & Ningbo & Jiaxing & $\begin{array}{l}\text { Total of the three } \\
\text { (or Average) }\end{array}$ \\
\hline $\begin{array}{l}\text { 1. Number of valid copies } \\
N=322 \text { (p) }\end{array}$ & $\begin{array}{c}162 \\
50.3 \% \\
\end{array}$ & $\begin{array}{c}62 \\
19.3 \% \\
\end{array}$ & $\begin{array}{c}98 \\
30.4 \% \\
\end{array}$ & $\begin{array}{c}322 \\
100 \% \\
\end{array}$ \\
\hline Boy (person) & $\begin{array}{c}87 \\
53.7 \% \\
\end{array}$ & $\begin{array}{c}24 \\
38.7 \% \\
\end{array}$ & $\begin{array}{c}46 \\
46.9 \% \\
\end{array}$ & $\begin{array}{c}157 \\
48.8 \% \\
\end{array}$ \\
\hline Girl (person) & $\begin{array}{c}75 \\
46.3 \% \\
\end{array}$ & $\begin{array}{c}38 \\
61.3 \% \\
\end{array}$ & $\begin{array}{c}52 \\
53.1 \% \\
\end{array}$ & $\begin{array}{c}165 \\
51.2 \% \\
\end{array}$ \\
\hline Only child (person) & $\begin{array}{c}10 \\
6.2 \%\end{array}$ & $\begin{array}{c}6 \\
9.7 \%\end{array}$ & $\begin{array}{c}8 \\
8.2 \%\end{array}$ & $\begin{array}{c}24 \\
7.5 \%\end{array}$ \\
\hline $\begin{array}{l}\text { 2. Number of children attending kindergartens } \\
\text { N1=143 (person) }\end{array}$ & $\begin{array}{c}18 \\
12.6 \% \\
\end{array}$ & $\begin{array}{c}55 \\
38.5 \% \\
\end{array}$ & $\begin{array}{c}70 \\
49.0 \% \\
\end{array}$ & $\begin{array}{c}143 \\
100 \%\end{array}$ \\
\hline $\begin{array}{l}\text { Number of children attending public kindergarten } \\
\text { (person) }\end{array}$ & $\begin{array}{c}13 \\
72.2 \% \\
\end{array}$ & $\begin{array}{c}45 \\
81.8 \% \\
\end{array}$ & $\begin{array}{c}54 \\
77.1 \% \\
\end{array}$ & $\begin{array}{c}112 \\
78.3 \% \\
\end{array}$ \\
\hline $\begin{array}{l}\text { Average tuition of public kindergarten } \\
\text { (¥Yuan/term) }\end{array}$ & 3100 & 2990 & 2890 & 2993 \\
\hline $\begin{array}{l}\text { Number of people can afford tuition of public } \\
\text { kindergarten (person) }\end{array}$ & $\begin{array}{c}13 \\
100 \% \\
\end{array}$ & $\begin{array}{c}45 \\
100 \% \\
\end{array}$ & $\begin{array}{c}54 \\
100 \% \\
\end{array}$ & $\begin{array}{c}112 \\
100 \% \\
\end{array}$ \\
\hline $\begin{array}{l}\text { Number of children attend private kindergarten } \\
\text { (person) }\end{array}$ & $\begin{array}{c}5 \\
27.8 \% \\
\end{array}$ & $\begin{array}{c}10 \\
18.2 \% \\
\end{array}$ & $\begin{array}{c}16 \\
22.9 \% \\
\end{array}$ & $\begin{array}{c}31 \\
21.7 \% \\
\end{array}$ \\
\hline $\begin{array}{l}\text { Average tuition of private kindergarten } \\
\text { (¥Yuan/term) }\end{array}$ & 5600 & 4990 & 5320 & 5303 \\
\hline $\begin{array}{l}\text { Number of people can afford tuition of private } \\
\text { kindergarten (person) }\end{array}$ & $\begin{array}{c}5 \\
100 \% \\
\end{array}$ & $\begin{array}{c}10 \\
100 \% \\
\end{array}$ & $\begin{array}{c}16 \\
100 \% \\
\end{array}$ & $\begin{array}{c}31 \\
100 \% \\
\end{array}$ \\
\hline $\begin{array}{l}\text { Number of parents accompanying children to } \\
\text { kindergarten }(\mathrm{P})\end{array}$ & $\begin{array}{c}10 \\
55.6 \% \\
\end{array}$ & $\begin{array}{c}31 \\
56.4 \% \\
\end{array}$ & $\begin{array}{c}38 \\
54.3 \% \\
\end{array}$ & $\begin{array}{c}79 \\
55.2 \% \\
\end{array}$ \\
\hline $\begin{array}{l}\text { Number of grandparents accompanying children } \\
\text { to kindergarten }(\mathrm{P})\end{array}$ & $\begin{array}{c}8 \\
44.4 \% \\
\end{array}$ & $\begin{array}{c}24 \\
43.6 \% \\
\end{array}$ & $\begin{array}{c}27 \\
38.6 \% \\
\end{array}$ & $\begin{array}{c}59 \\
41.3 \% \\
\end{array}$ \\
\hline Number of taking kindergarten bus & $\begin{array}{c}0 \\
0 \% \\
\end{array}$ & $\begin{array}{c}0 \\
0 \% \\
\end{array}$ & $\begin{array}{c}5 \\
7.1 \% \\
\end{array}$ & $\begin{array}{c}5 \\
3.5 \% \\
\end{array}$ \\
\hline $\begin{array}{l}\text { 3. Number of pupils } \\
\text { N2=179 (person) }\end{array}$ & $\begin{array}{c}144 \\
80.4 \% \\
\end{array}$ & $\begin{array}{c}8 \\
4.5 \% \\
\end{array}$ & $\begin{array}{c}27 \\
15.1 \% \\
\end{array}$ & $\begin{array}{c}179 \\
100 \%\end{array}$ \\
\hline Number of public school pupils (person) & $\begin{array}{c}144 \\
100 \% \\
\end{array}$ & $\begin{array}{c}8 \\
100 \% \\
\end{array}$ & $\begin{array}{c}27 \\
100 \% \\
\end{array}$ & $\begin{array}{c}179 \\
100 \% \\
\end{array}$ \\
\hline Average tuition of public school (¥Yuan/term) & 0 & 0 & 0 & 0 \\
\hline Number of private school pupils (person) & 0 & 0 & 0 & 0 \\
\hline Average tuition of private (Thousand ¥Yuan/term) & $10-20$ & $10-20$ & $10-20$ & $10-20$ \\
\hline $\begin{array}{l}\text { Number of people who can afford tuition of private } \\
\text { school (person) }\end{array}$ & $\begin{array}{c}0 \\
0 \% \\
\end{array}$ & $\begin{array}{c}0 \\
0 \% \\
\end{array}$ & $\begin{array}{c}0 \\
0 \%\end{array}$ & $\begin{array}{c}0 \\
0 \% \\
\end{array}$ \\
\hline $\begin{array}{l}\text { Number of parents accompanying children to } \\
\text { school (person) }\end{array}$ & $\begin{array}{c}50 \\
34.7 \% \\
\end{array}$ & $\begin{array}{c}3 \\
37.5 \% \\
\end{array}$ & $\begin{array}{c}14,51 \\
9 \%\end{array}$ & $\begin{array}{c}67 \\
37.4 \% \\
\end{array}$ \\
\hline $\begin{array}{l}\text { Number of grandparents accompanying children to } \\
\text { school (person) }\end{array}$ & $\begin{array}{c}62 \\
43.1 \% \\
\end{array}$ & $\begin{array}{c}2 \\
25.0 \% \\
\end{array}$ & $\begin{array}{c}3 \\
11.1 \% \\
\end{array}$ & $\begin{array}{c}67 \\
37.4 \% \\
\end{array}$ \\
\hline Number of students taking school bus & $\begin{array}{c}2 \\
1.4 \% \\
\end{array}$ & $\begin{array}{c}0 \\
0 \% \\
\end{array}$ & $\begin{array}{c}0 . \\
0 \% \\
\end{array}$ & $2,1.1 \%$ \\
\hline
\end{tabular}


Weijia Gao, Yingying Ge, Yiting Feng, Shuqin Jiang, Man Wu, Yang Feng THE CURRENT SITUATION OF FAMILY EDUCATION AND SCHOOL AND KINDERGARTEN ADMISSION OF MIGRANT CHILDREN IN ZHEJIANG PROVINCE, CHINA: A SURVEY OF HANGZHOU, NINGBO AND JIAXING

\begin{tabular}{|c|c|c|c|c|}
\hline Numbers of students walking or by bus & $\begin{array}{c}30, \\
20.8 \% \\
\end{array}$ & $\begin{array}{c}3 \\
37.5 \% \\
\end{array}$ & $\begin{array}{c}10 \\
37.0 \% \\
\end{array}$ & $\begin{array}{c}43 \\
24.0 \% \\
\end{array}$ \\
\hline $\begin{array}{l}\text { 4. Parent-child reading } \\
\mathrm{N}=322(\mathrm{P})\end{array}$ & $n=162$ & $n=62$ & $\mathrm{n}=98$ & Total of the three \\
\hline Everyday (person) & $\begin{array}{c}5 \\
3.0 \% \\
\end{array}$ & $\begin{array}{c}6 \\
9.7 \% \\
\end{array}$ & $\begin{array}{c}5 \\
5.1 \% \\
\end{array}$ & $\begin{array}{c}16 \\
5.0 \% \\
\end{array}$ \\
\hline Often (person) & $\begin{array}{c}27 \\
16.7 \% \\
\end{array}$ & $\begin{array}{c}3 \\
4.8 \% \\
\end{array}$ & $\begin{array}{c}2 \\
2.0 \% \\
\end{array}$ & $\begin{array}{c}32 \\
10.0 \% \\
\end{array}$ \\
\hline Rarely (person) & $\begin{array}{c}115 \\
71.0 \% \\
\end{array}$ & $\begin{array}{c}38 \\
61.3 \% \\
\end{array}$ & $\begin{array}{c}88 \\
89.8 \% \\
\end{array}$ & $\begin{array}{c}241 \\
75.0 \%\end{array}$ \\
\hline Never (person) & $\begin{array}{c}15 \\
9.3 \% \\
\end{array}$ & $\begin{array}{c}15 \\
24.2 \% \\
\end{array}$ & $\begin{array}{c}3 \\
3.1 \% \\
\end{array}$ & $\begin{array}{c}33 \\
10.0 \% \\
\end{array}$ \\
\hline $\begin{array}{l}\text { 5. Parent-child physical exercise } \\
\mathrm{N}=322\end{array}$ & & & & Total of the three \\
\hline Everyday (person) & $\begin{array}{c}3 \\
1.9 \% \\
\end{array}$ & $\begin{array}{c}6 \\
9.7 \% \\
\end{array}$ & $\begin{array}{c}6 \\
6.1 \% \\
\end{array}$ & $\begin{array}{c}15 \\
4.7 \% \\
\end{array}$ \\
\hline Often (person) & $\begin{array}{c}90 \\
55.6 \% \\
\end{array}$ & $\begin{array}{c}29 \\
46.8 \% \\
\end{array}$ & $\begin{array}{c}27 \\
27.6 \% \\
\end{array}$ & $\begin{array}{c}146 \\
45.3 \% \\
\end{array}$ \\
\hline Rarely (person) & $\begin{array}{c}66 \\
40.7 \% \\
\end{array}$ & $\begin{array}{c}19 \\
30.6 \% \\
\end{array}$ & $\begin{array}{c}59 \\
60.2 \% \\
\end{array}$ & $\begin{array}{c}144 \\
44.7 \% \\
\end{array}$ \\
\hline Never (person) & $\begin{array}{c}3 \\
1.9 \% \\
\end{array}$ & $\begin{array}{c}8 \\
12.9 \% \\
\end{array}$ & $\begin{array}{c}6 \\
6.1 \% \\
\end{array}$ & $\begin{array}{c}17 \\
5.3 \% \\
\end{array}$ \\
\hline $\begin{array}{l}\text { 6. Homework counseling } \\
\mathrm{N}=322(\mathrm{P})\end{array}$ & & & & Total of the three \\
\hline Everyday (person) & $\begin{array}{c}18 \\
11.1 \% \\
\end{array}$ & $\begin{array}{c}14 \\
22.6 \% \\
\end{array}$ & $\begin{array}{c}16 \\
16.3 \% \\
\end{array}$ & $\begin{array}{c}48 \\
14.9 \% \\
\end{array}$ \\
\hline Often (person) & $\begin{array}{c}54 \\
33.3 \% \\
\end{array}$ & $\begin{array}{c}8 \\
12.9 \% \\
\end{array}$ & $\begin{array}{c}18 \\
18.4 \% \\
\end{array}$ & $\begin{array}{c}80 \\
24.8 \% \\
\end{array}$ \\
\hline Rarely (person) & $\begin{array}{c}78 \\
48.1 \% \\
\end{array}$ & $\begin{array}{c}35 \\
56.5 \% \\
\end{array}$ & $\begin{array}{c}64 \\
65.3 \% \\
\end{array}$ & $\begin{array}{c}177 \\
55.0 \% \\
\end{array}$ \\
\hline Never ( person) & $\begin{array}{c}12 \\
7.4 \% \\
\end{array}$ & $\begin{array}{c}5 \\
8.1 \% \\
\end{array}$ & $\begin{array}{c}0 \\
0 \% \\
\end{array}$ & $\begin{array}{c}17 \\
5.3 \% \\
\end{array}$ \\
\hline $\begin{array}{l}\text { 7. Instruct child on hand making } \\
\mathrm{N}=322\end{array}$ & $n=162$ & $n=62$ & $\mathrm{n}=98$ & Total of the three \\
\hline Often (person) & $\begin{array}{c}3 \\
1.9 \% \\
\end{array}$ & $\begin{array}{c}0 \\
0 \% \\
\end{array}$ & $\begin{array}{c}2 \\
2.0 \% \\
\end{array}$ & $\begin{array}{c}5 \\
1.6 \% \\
\end{array}$ \\
\hline Rarely (person) & $\begin{array}{c}51 \\
31.5 \% \\
\end{array}$ & $\begin{array}{c}26 \\
41.9 \% \\
\end{array}$ & $\begin{array}{c}70 \\
71.4 \% \\
\end{array}$ & $\begin{array}{c}147 \\
45.7 \% \\
\end{array}$ \\
\hline Never (person) & $\begin{array}{c}108 \\
66.7 \% \\
\end{array}$ & $\begin{array}{c}36 \\
58.1 \% \\
\end{array}$ & $\begin{array}{c}26 \\
26.5 \% \\
\end{array}$ & $\begin{array}{c}170 \\
52.8 \% \\
\end{array}$ \\
\hline $\begin{array}{l}\text { 8. Develop child's specialties } \\
\mathrm{N}=322\end{array}$ & & & & Total of the three \\
\hline Often (person) & $\begin{array}{c}38 \\
23.5 \% \\
\end{array}$ & $\begin{array}{c}21 \\
33.9 \% \\
\end{array}$ & $\begin{array}{c}14 \\
14.3 \% \\
\end{array}$ & $\begin{array}{c}73 \\
22.7 \% \\
\end{array}$ \\
\hline Rarely (person) & $\begin{array}{c}47 \\
29.0 \% \\
\end{array}$ & $\begin{array}{c}15 \\
24.2 \% \\
\end{array}$ & $\begin{array}{c}50 \\
51.0 \% \\
\end{array}$ & $\begin{array}{c}112 \\
34.8 \% \\
\end{array}$ \\
\hline Never (person) & $\begin{array}{c}77 \\
47.5 \% \\
\end{array}$ & $\begin{array}{c}26 \\
41.9 \% \\
\end{array}$ & $\begin{array}{c}34 \\
34.7 \% \\
\end{array}$ & $\begin{array}{c}137 \\
42.5 \% \\
\end{array}$ \\
\hline $\begin{array}{l}\text { 9. Children in tutoring classes } \\
\mathrm{N}=322\end{array}$ & & & & Total of the three \\
\hline No class (person) & $\begin{array}{c}106 \\
65.4 \% \\
\end{array}$ & $\begin{array}{c}42 \\
67.7 \% \\
\end{array}$ & $\begin{array}{c}78 \\
80.0 \% \\
\end{array}$ & $\begin{array}{c}226 \\
70.2 \% \\
\end{array}$ \\
\hline One class (person) & $\begin{array}{c}16 \\
9.9 \% \\
\end{array}$ & $\begin{array}{c}18 \\
29.0 \% \\
\end{array}$ & $\begin{array}{c}5 \\
5.1 \% \\
\end{array}$ & $\begin{array}{c}39 \\
12.1 \% \\
\end{array}$ \\
\hline
\end{tabular}




\begin{tabular}{|l|c|c|c|c|}
\hline Two classes (person) & 37 & 2 & 9 & 48 \\
& $22.8 \%$ & $3.2 \%$ & $9.2 \%$ & $14.9 \%$ \\
\hline Three or more classes (person) & 3 & 0 & 6 & 9 \\
\hline $\begin{array}{l}\text { 10. Children's hobby at home } \\
\text { N=322 }\end{array}$ & $1.9 \%$ & $0 \%$ & $6.1 \%$ & $2.8 \%$ \\
\hline Watch TV (person) & & & & Total of the three \\
\hline Play computer games (person) & 37 & 21 & 30 & 88 \\
\hline Read books (person) & $22.8 \%$ & $33.9 \%$ & $30.6 \%$ & $27.3 \%$ \\
\hline Do sports (person) & 30 & 14 & 37 & 81 \\
\hline Others (person) & $18.5 \%$ & $22.6 \%$ & $37.6 \%$ & $25.2 \%$ \\
\hline 11. Average books at home & 18 & 6 & 15 & 39 \\
(volume) & 26 & $9.7 \%$ & $15.3 \%$ & $12.1 \%$ \\
\hline
\end{tabular}

\subsection{Basic situation of the respondents}

\subsubsection{Population of respondents}

The number of valid respondents in Hangzhou, Ningbo, and Jiaxing are 322, of which 162 were in Hangzhou, 50\%; 98 in Jiaxing, 31\%; and 62 in Ningbo, accounting for 19\%.

\subsubsection{Gender ratio of survey respondents}

The number of valid questionnaires in the survey of the three cities was 322, including 165 boys (51\%) and 157 girls (49\%).

\subsubsection{Situation of siblings}

Among the respondents, 24 were the only child (7.5\%), and 126 have one brother or sister (39.1\%), 93 have two brothers and sisters (28.9\%); 53 have three brothers and sisters (16.5\%); 26 have four and even more brothers and sisters (8.1\%).

\subsubsection{Time to come to Zhejiang}

Among the respondents, 14 people have come to Zhejiang for 1-3 years (4.3\%); 75 people have come for 7-6 years (23.3\%), 141 people have come for 7-10 years (43.8\%), 92 people have come for over 10 years $(28.6 \%)$.

\subsubsection{Household registration}

Among the respondents, the proportion of household registration in rural areas was $94 \%$, and that in other cities was $6 \%$. 


\subsection{Admission to the kindergartens and primary schools}

A. The survey found that the average tuition fee of public kindergartens in these three places is 2,993 RMB per semester, that is, about 700RMB per month, which can be accepted, and most parents think the price is inexpensive.

In these cities, if children with non-local household registration want to enroll in public kindergartens and primary schools, parents must meet the requirements of having legal and stable employment and residence in the local area, and with continuous payment of social insurance (excluding supplementary payment) for more than one year in the local urban area. For those schools with limited number of places, the quantitative score of residence permit of both parents or one of them should be ranked in order and those who rank at the top will be accepted by the schools. (Hangzhou Municipal Government, 2017).

Those parents who do not meet the requirements of public schools enrollment, or although they meet the requirements, the schools' quota is full, can go to private kindergarten, but the tuition is 2-3 times or even higher than that of public schools. So for non-local household registration families, there still have problems of expensive tuition fee and enrollment difficulty.

B. Those qualified children with non-local household registration will stay with their parents and go to local schools, which belong to compulsory education, with completely free tuition and book. While those who can't meet the requirements, parents can choose the local private schools, which also means that their tuition fees can be tens of thousands yuan per year. Therefore, all school-aged migrant children and most pre-school migrant children who do not meet the requirements for admission to public primary schools will go back to their hometown for school education due to the pressure of tuition fees.

\subsection{Family education}

\subsubsection{Parent-child reading}

Among the respondents, 16 parents (5\%) read with their children every day; 32 parents (10\%) often read with their children; 241 parents $(75 \%)$ seldom read with their children; 33 parents $(10 \%)$ never have parent-child reading.

\subsubsection{Parent-child physical exercise}

Among the respondents, 15 parents (5\%) have parent-child physical exercise every day; 146 parents are regular participants, accounting for $45 \%$; 144 parents (45\%) seldom work out with their children; 17 parents (5\%) never have parent-child physical exercise. 


\subsubsection{Homework guidance}

Among the respondents, 48 parents (15\%) give homework guidance to their children everyday; 80 parents (15\%) often help with their children's homework; 177 parents (55\%) rarely do that; 17 parents (5\%) never give homework guidance.

\subsubsection{Instruction on handcraft}

Among the respondents, 5 parents (1\%) often instruct children in handcraft; 147 parents (46\%) hardly do; 170 parents (53\%) never do.

\subsubsection{Extension of children's special skill}

Among the respondents, 73 parents (23\%) think highly of cultivation of children's strong point; 112 parents (35\%) pay little attention to it; 137 parents (43\%) never think about it.

\subsubsection{Number of children's training class}

Among the respondents, 226 parents' children (70\%) don't go to any tutoring class; 39 parents (12\%) arrange one class for their children; 48 parents (15\%) arrange two classes for their children; 9 parents $(3 \%)$ have arrange three or more than three classes for children.

\subsubsection{Extracurricular activities (what do children like to do at home)}

Among the respondents, 88 children (27\%) like watching TV; 81 children (25\%) play computer games; 39 children (12\%) do reading; 41 children (13\%) play sports; 73 children do other things $(23 \%)$.

\section{Conclusions and suggestions}

\subsection{Conclusion}

The main results are as follows:

A. nearly $70 \%$ of the parents of migrant children in Zhejiang Province have been working in the province for $5-10$ years, $28 \%$ of them have been working in the province for more than 10 years, $94 \%$ of them are registered in rural areas and $6 \%$ in small towns outside Zhejiang. Nearly $70 \%$ of these families have 2 to 3 children and $16 \%$ have 4 children. Migrant children in Zhejiang cities go to public primary schools. All school-aged children and most preschool children who do not meet the admission requirements return to their hometown because of the pressure of tuition fees.

B. The family education of migrant children in Zhejiang is not ideal, the learning environment of family education is not good, there is no tutoring in homework after class, more than half of the children's extracurricular time is occupied by television and video games, and the proportion of reading and physical activities is only a little more than $10 \%$. Most parents have a prominent phenomenon of 
inter-generational education, with little or no reading, homework, physical exercise with their children.

C. The main causes are as follows:

a. The pressure of living in mobile families is obviously higher than that in local families. Parents are busy working for their livelihood. Due to heavy work and low education, the communication between parents and children is limited, lack of enough time to understand their children's learning status and mental health, and alienation of parent-child relationship.

b. The educational level of parents of migrant children is limited, the way of family education is not scientific, and there is a lack of scientific concept of family education.

c. Parents often change their working units, and families are also moving frequently to ensure that children's growing environment is not guaranteed.

d. Relatively weak economic conditions limit the level of investment in education for children.

\subsection{Suggestions}

Solving the problem of compulsory education for migrant children is an important part of effectively protecting their legitimate rights and interests and safeguarding education equity. We must attach great importance to and solve the educational problems of migrant children from the strategy of building a harmonious society.

A. Initiate all aspects of society and actively improve school conditions. The education of migrant children involves many government functional departments and requires active cooperation between the education, finance, taxation, public security, judicial, labor security, civil affairs, industry and commerce, and price departments. Therefore, it is necessary to strengthen the leading role of the government. It is necessary to clarify and implement the responsibility of government to the compulsory education of migrant children. This will enable the migrants to settle in their jobs and continue to make great contributions to the city's economic construction and social development.

B. Raise funds through multiple channels. Insufficient funding for education is a constraint to solving the education of migrant children. Therefore, it is necessary to raise funds for running schools through multiple channels. Groups and individuals with economic strength should be encouraged to support the teaching venues, teaching equipment, teaching materials, human resources and funds required for migrant children to enter school.

C. Strengthen the scientific management of student status and provide more convenience for migrant children to attend school. In the management of compulsory education for migrant children, we should actively explore the management system that meets the characteristics of migrant children's education 
and ensure that all migrant children can enter free public schools in the cities where they live.

D. Break the opposition structure of urban and rural education and accelerate the management of household registration. Solve the problem of migrant children's education so that they can not only receive education, but also receive qualified education. In the teaching process, we fully consider the learning foundation and adaptability of rural students and teach students in accordance with their aptitude.

E. Extensively carry out the volunteer education activities of college students and retired teachers to help migrant children to carry out homework and reading and improve their academic level.

\section{References}

Chen, X. (2019). Family education problems and strategies of migrant children. Mental Health Education in Primary and Secondary Schools, (02), 12-17.

Hangzhou Municipal Government. (2019). Measures for the Administration of Preschool Education and Compulsory Education for Migrant Children in Hangzhou (Trial). Retrieved from: http://www.hangzhou.gov.cn/art/2017/9/13/art .html

Liu, J. \& Li, Y. (2019). Care for mobility: a study of preschool education supports for migrant children in urban villages from the perspective of family public policy. Children's Research, (08), 4-18.

United Nations International Children's Emergency Fund. (2015). Population Status of Children in China in 2015: Facts and Figures. Retrieved from: https://www.unicef.cn/sites/unicef.org.china/files/201903/2015\%E5\%B9\%B4\%E4\%B8\%AD\%E5\%9B\%BD\%E5\%84\%BF\%E7\%AB\%A5\%E4 \%BA\%BA\%E5\%8F\%A3\%E7\%8A\%B6\%E5\%86\%B5\%E2\%80\%94\%E2\%80\%94\%E4 \%BA $\% 8$ B $\%$ E5\%AE $\% 9 \mathrm{E} \% \mathrm{E} 4 \% \mathrm{~B} 8 \% 8 \mathrm{E} \% \mathrm{E} 6 \% 95 \% \mathrm{~B} 0 \% \mathrm{E} \% 8 \mathrm{D} \% \mathrm{AE} . \mathrm{pdf}$

Wang, S. Sociological thinking on the functional change of traditional rural family education. China National Expo, 2020, (10), 85-86.

Zhou, Y., Huang, Y., Zhou, Y. (2019). Social integration of urban migrant workers: a survey of migrant workers in Zhejiang Province. Science and Technology Entrepreneurship Monthly, 32 (05), 144-146.

Zhang, S., Chen, D., Su, M., Qi, Y. (2017). Current situation and Countermeasures of family education of migrant children. China Special Education, (07),47-52. 
Weijia Gao, Yingying Ge, Yiting Feng, Shuqin Jiang, Man Wu, Yang Feng

THE CURRENT SITUATION OF FAMILY EDUCATION AND SCHOOL AND KINDERGARTEN

ADMISSION OF MIGRANT CHILDREN IN ZHEJIANG PROVINCE, CHINA:

A SURVEY OF HANGZHOU, NINGBO AND JIAXING

Creative Commons licensing terms

Author(s) will retain the copyright of their published articles agreeing that a Creative Commons Attribution 4.0 International License (CC BY 4.0) terms will be applied to their work. Under the terms of this license, no permission is required from the author(s) or publisher for members of the community to copy, distribute, transmit or adapt the article content, providing a proper, prominent and unambiguous attribution to the authors in a manner that makes clear that the materials are being reused under permission of a Creative Commons License. Views, opinions and conclusions expressed in this research article are views, opinions and conclusions of the author(s). Open Access Publishing Group and European Journal of Education Studies shall not be responsible or answerable for any loss, damage or liability caused in relation to/arising out of conflicts of interest, copyright violations and inappropriate or inaccurate use of any kind content related or integrated into the research work. All the published works are meeting the Open Access Publishing requirements and can be freely accessed, shared, modified, distributed and used in educational, commercial and non-commercial purposes under a Creative Commons Attribution 4.0 International License (CC BY 4.0). 